\title{
高温機器における余寿命診断技術開発の最前線 The Frontier of Technology Development in Remaining Life Assessment for High Temperature Components
}

近年, 破壊事故が人的, 経济的あるいは環境面で大きな損害を招くことになる機器・構造物における保守管理の最適 化と高度化がますます重要となっている。特に，2011年 3 月 11 日の東日本大震災以降，運転休止プラントを再稼働す るなど, 需要が急増している火力発電プラントにおいては, その安全性と信頼性を確保しつつ長期間安定に運用するこ とが強く求められている.

ボイラやタービンなど火力発電プラントの高温機器に生じる劣化・損傷を検出し，笛の余寿命や健全性を評価する方 法には破壊試験法や非破壊評価法がある。破壊試験法は，実機部材から試料をサンプリングし，引張試験やクリープ試 験などの破壊試験を行って劣化・損傷度を直接評価するものである。一方, 長期供用中のナノ・ミクロ組織の変化とそ れに伴う物理・化学的性質の変化，あるいはクリープボイドを計測して，劣化・損傷度との関係を検討し余寿命を予測 するのが非破壊評価法である。しかし，従来手法の予測精度は，例えば“Factor of 2 ” と称されているように倍・半分程度 の精度であり, 決して満足いくものではない. 予測精度のより一層の向上を実現するには, 従来の古典的手法にとらわ れることなく, 高度化された先端的技術を取り込んだ新しい手法の研究・開発が不可欠である。このような中, 2006 年 には，耐熱材料のミク口損傷の統合的な計測・評価法とその知見を反映した実用的な非破壊評価法の確立を目的とした “損傷評価 WG” と高温機器の余寿命診断のための微小サンプルクリープ試験法標準の提案を目的とした “微小サンプ ルクリープ試験法 WG”が日本材料学会・高温強度部門委員会内に発足した。

本連載講座では, 高温機器における余寿命診断技術開発の最前線というテーマで 4 回連載の講座を企画し，余寿命評 価の高精度・高度化につながると注目されている最新の非破壊評価法や余寿命診断技術を紹介する。第 1 回「EBSD 観

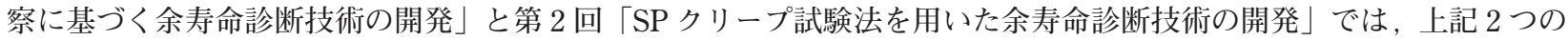
WGにおける活動内容の紹介や成果報告も一部含まれている。また，第 3 回「実機高温ひずみ計測による余寿命診断技 術の開発」と第 4 回「電磁超音波共鳴法を用いた余寿命診断技術の開発」では，実機のひずみ測定技術と超音波特性 の変化に着目した評価技術に関する最新の研究動向をそれぞれ紹介する。本連載講座における一連の解説が, 本学会員, 関連分野の研究者および技術者の方々の今後の研究・開発活動の一助になれば幸いである.

\section{EBSD 観察に基づく余寿命診断技術の開発}

\section{藤 山一 成* \\ I : Technology Development in Remaining Life Assessment Based on EBSD Observation}

by

\author{
Kazunari FuJIYAMA*
}

Key words : EBSD, Misorientation, Creep, Creep-fatigue, Damage, Strain, Dislocation, Life assessment

\section{1 は じめに}

EBSD (Electron BackScatter Diffraction) 法 ${ }^{1)} は$, 材料 表面の結晶構造に関するデジタル情報をもとに，材料の 微視構造を明らかにすることができる手段として幅広く 利用されている。EBSD で得られる方位差情報は，材料 の転位分布と密接に関係していることから，ひずみや損 傷の指標になりうるものとして，まず室温における塑性 ひずみの評価と高サイクル疲労に関する研究が活発に行 われ，その後，高温に打けるクリープやクリープ疲労に ついての研究が活発になってきている。その中で, 2006
年には，日本材料学会高温強度部門委員会内に損傷評価 WG が発足し，まずEBSD による損傷評価法に必要な試 験条件の明確化とラウンドロビン試験によるデータ比較 が行われた。本活動の中で, EBSD 法が損傷の実体の理 解に極めて有効な手段であり，また，EBSD 観察から得 られる情報の物理的意味を明確にして評価を行うことが 必要であるという認識が得られた。

本稿では，EBSD 法によるひずみ評価手段に関する研 究動向を概観した後，上記損傷評価 WG での情報交換な どにより得られた高温クリープやクリープ疲労に関する 
最近の研究動向を紹介し, 本手法の有効性や今後の課題 と方向性について解説する。な打，本稿は結晶解析の専 門家からみた整密な内容を解説したものではなく，それを 利用しようとする機械系研究者からみた記述であること をご理解いただきたい．また次節の記述の多くは文献 2) を参照しているが，本文献は EBSD ユーザー用で一般販 売されているものではないことをお断りしておく.

\section{2 損傷評価のための EBSD 観察法の概要 $2 \cdot 1$ EBSD 装置 ${ }^{2)}$}

EBSD 観察は, 図 1 (a) (b) に示すように走査型電子顕 微鏡 $(\mathrm{SEM})$ の試料台を水平から $70^{\circ}$ 傾け，電子ビーム を照射し, 試料表面に進入した電子線から非弾性散乱に よって生じる円錐状の回折コーンを垂直面で検出して行 われる. 回折格子面の電子ビーム進行側（図では下側） への散乱は強度が強く, その回折線は検出面の上側に明 線として現れ，反対側は暗線となる。検出面上ではこの 2 つの線がバンドを構成している。 円錐を平面で切って いることから検出面上の線は曲率を持つがほとんど目立 たない. また垂直方向の格子面から得られる散乱線の組 は上下の強度差が無いため明線・暗線の区別はない. バ ンド幅は 2 つのコーン間の角度に相当し, 回折角の 2 倍 となる。

図 2 (a)に, 検出面で得られる回折パターンの例を示す. EBSD 解析装置は，ここで得られる菊池線パターンに着 目して方位を決定するが，そのためには予め測定する試 料の結晶系情報を与えておく必要がある。図 2 (b)に示す ようにその情報を基にバンド間の角度と結晶面間の角度 とを比較して面の指数付けが行なわれる.

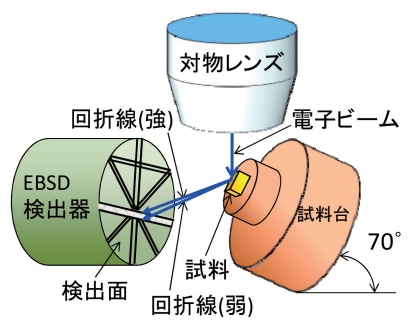

(a)EBSD 観察部機器構成の模式図

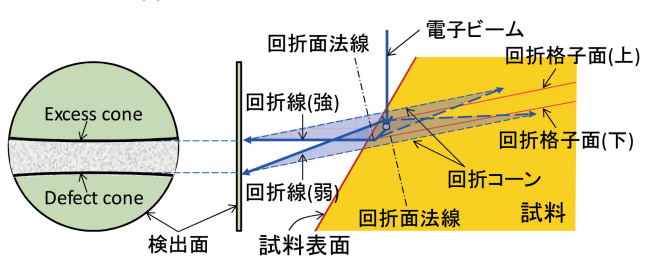

(b)電子ビームと回折線の進路を示す断面図

図 1 EBSD 観察系の模式図

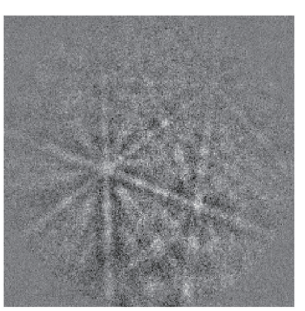

(a)回折パターン

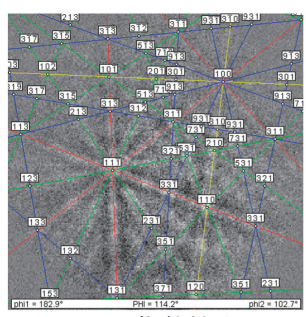

(b)指数付け
図 $2 \mathrm{EBSD}$ 回折パターンとバンドへの指数付け

\section{$\mathbf{2} \cdot \mathbf{2}$ 試料の準備 2$)$}

通常，試料の観察面の準備は，ダイヤモンドペースト による鏡面研磨後に，コロイダルシリカ粵濁液を用いて パフ研磨などにより仕上げて行われる。

EBSD 観察においては，極めて軽微なエッチング面で 観察できることから, 結晶粒界, すべり帯，微小き裂や クリープボイドなどの凹凸形状をあまり損なうことなく 観察できることが大きな利点である.

\section{$2 \cdot 3$ 方位マップ2)}

方位のパラメータとしては，画像上の観察単位である 各ピクセルについて空間座標と結晶軸の 3 方向の間の才 イラー角の值が得られる。これを画像全体のピクセルにわ たってスキャンして 1 画像のデジタルデータとなる。方位 解析結果の信頼性や結晶性の良否を調べるためのマップ としては，例えば図 3 (a) (b) に示す CI（信頼性指数 Confidence Index) マップや IQ (Image Quality) マップ などがあり, CI 值（0～10值を取る）が高いほど指数 付けの信頼性が高く，IQ 值が高いほど結晶性が良く乱れ が少ないことを示している。ただし，これらは観察条件 によって変動する值であるため, 損傷評価の定量的パラ メータにはなりにくい面がある.

図 4 にSUS304HTB の未使用材と 50\% クリープ損傷材 について得られたIPF（Inverse Pole Figure, 逆極点困 方位）マップを示す。未使用材では結晶粒内はほぼ一様 な色調で表示され, 粒内での方位差が無いことを示して いるが，50\%クリープ損傷材では粒内に色調の乱れが生じ ており，方位差が現れてきていることを示している。この ように IPF マップは, 損傷に伴う粒内結晶方位の乱れや 結晶変形が把握できるが, 定量的数值指標を得るのには 必ずしも適していない，この他，ひずみに伴う結晶方位の 変化を見るのには Taylor 因子のマップも有効である.

\section{$2 \cdot 4$ 方位差マップ2}

ピクセル間の方位差は，ひずみ評価にとって極めて重 要なパラメータである。よく使わ机る指標には次の 4 種 類がある. 以下では図 5 に示す 6 角形ピクセルについて 説明するが，これ以外に正方形のピクセルもある.

(1) KAM (Kernel Average Misorientation, 四 5 (a)): 評価対象ピクセル (E) に隣接する 6 ピクセル間の方

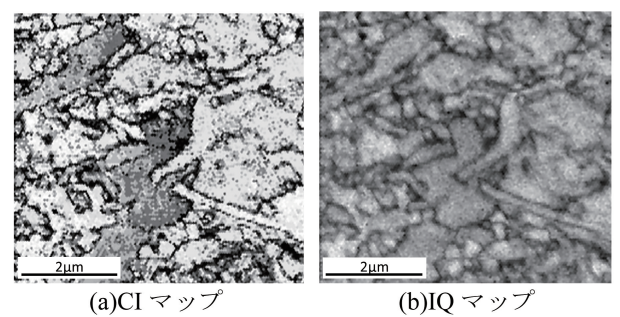

図 3 方位解析結果の信頼性と結晶性を判定するマップ

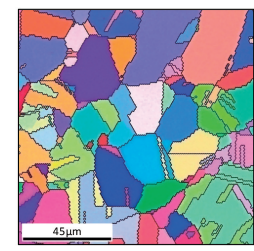

(a)末使用材

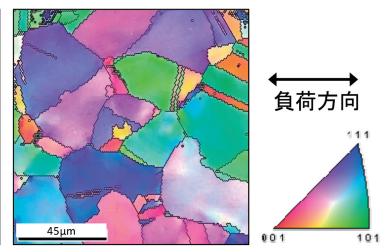

(b) $50 \%$ クリープ損傷材 (c)方位
図 4 SUS304HTB の IPF マップ例 
位差（角度）の平均值. 同一結晶粒内のみで計算. 粒内の各点の方位差がわかるが，ピクセルサイズ (倍率) の影響を大きく受ける.

(2) GAM (Grain Average Misorientation) : KAM の粒 内全域にわたる平均で，1結晶粒につき 1 つの值を とる.

(3) GROD (Grain Reference Orientation Deviation, 図 5 (b))：1 結晶粒内での平均方位または最小 KAM 值となるピクセルを選び，粒内の他の各ピクセルと の方位差を示す．ピクセルサイズの影響を比較的受 けにくい

(4) GOS (Grain Orientation Spread) : 1 結晶粒内での 各ピクセルとその他のピクセルとの方位差を全ピク セルについて粒内で平均したもので 1 結晶粒につき 1つの值をとる。なお，これとは別の定義もある。

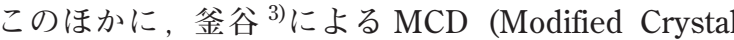
Orientation) がある。これは，1結晶粒内の中心方位か らの方位差が対数正規分布に従うとして平均操作した值 で, GROD の視野中の対数正規分布の平均值に相当する 指標となっている。

なお，以上の各值を観察領域全体にわたって平均化し た值を，以下では下付き aveの文字を付して表記する。

\section{$2 \cdot 5$ 結晶粒界の同定}

EBSD 解析における結晶粒界の方位差の設定は，材料 によって異なる。オーステナイト粒界はほぼ $15^{\circ}$ 以上で同 定されるが，焼戻しマルテンサイト組織などに見られるラ スやブロックなどの結晶内の境界については，1以上な いしは $5^{\circ}$ 以上の境界が設定される。後者はほぼブロック 境界に相当し，前者は一部のラス境界の情報も含むと考 えられる。な打 $1^{\circ}$ 以下の方位差に設定する場合は EBSD の精度上の限界に注意する必要がある。また，粒界の種 類の判定には，方位差だけでなく隣接粒間の方位関係も 調べる必要がある。

\section{$2 \cdot 6$ 方位差分布と結晶粒変形との関係}

方位差の結晶粒内分布と結晶全体の変形とは必ずしも 単純に対応するわけではない．例えば図 6 (a)に示すよう に，刃状転位が同方向に整列している場合，結晶粒は一

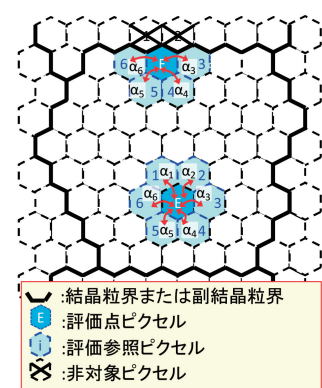

(a)KAM の定義

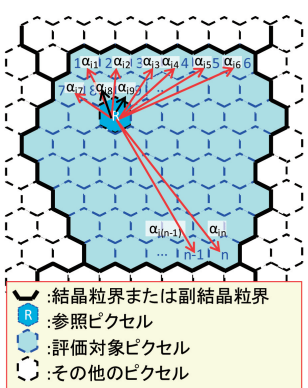

(b)GROD の定義
図 5 KAM および GROD の定義
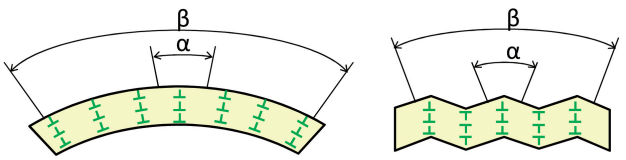

(a)転位壁が同方向 $(\beta>\alpha) \quad$ (b)転位壁が反対方向 $(\beta=\alpha)$ 図 6 転位分布と方位差の関係
方向にたわむ。しかし，反対符号の転位が図 6 (b)のよう に並んでいる場合には，結晶粒全体の変形とは直接対応 しない場合もある。このとき，GROD や GOSの值は小 さいが GAM の值は大きいという場合も生じ得る。また， 方位差は転位の密度と分布によって決まる值であり，転 位の移動によって生じる塑性やクリープなどの永久ひず みとそのまま対応するわけではない，損傷は，マクロ的 には永久ひずみの蓄積と密接に関係していることから， EBSD 法を損傷評価に用いるためには，永久ひずみとの 対応関係を明確にしておく必要がある。

\section{EBSD 観察にもとづくひずみおよび損傷評価}

\section{$3 \cdot 1$ 塑性ひずみ評価}

塑性ひずみを受けた材料を EBSD 測定すると，転位分 布が生じ回折パターンに変化が生じる。例えばオーステ ナイトステンレス鋼や炭素鋼などについて，KAM，GAM， GROD, MCD, GOS などのパラメータと塑性ひずみと の関係が検討されている. KAM や GAM は測定間隔（ピ クセルサイズ）の影響を受けるが，GROD，MCD，GOS などは測定間隔の影響を受けにくいとされている.

マクロなひずみ量との対応は, 結晶粒で平均化した GAM , GOS P MCD などが有効であるが, KAM や GROD は局所的な転位の分布に敏感な量であることから， 結晶粒内のひずみ分布評価に適していると考えられる。2)

また，引張りおよび圧縮試験による塑性ひずみと EBSD パラメータ $(\mathrm{GAM})$ との関係について差が無いことが報 告されている. ${ }^{4} \mathrm{GAM}$ と塑性ひずみ量との間に得られる関 係が線形となることは，試験条件によらず共通の傾向で あると考えられる。

\section{$3 \cdot 2$ 高サイクル疲労損傷評価}

高サイクル疲労においては, すべり帯の形成とき裂の発 生について, 結晶構造との関係から調べる手段として EBSD が用いられている. 特に，すべり系に関して Schmid 因子や Taylor 因子が容易に求められるため，主すべり系 やその他のすべり系を同定することができる

王ら ${ }^{5)}$ は，原子力用熱関圧延 SUS316NG 鋼のねじり疲 労試験において，結晶方位とSchmid 因子を求め, 外部 応力が各結晶に作用すると考えて, 各結晶粒における活 動すべり系を求めることが可能であることを示した。さ らに，疲労き裂を粒界き裂，双晶粒界き裂，すべり帯き 裂，粒内き裂の 4 種類に分類し，それぞれの方向につい て検討している.

\section{$3 \cdot 3$ クリープ損傷評価}

耐熱材料のクリープ損傷過程においては，転位組織や 結晶下部組織の変化と結晶粒変形，および結晶粒界に発 生するクリープボイドなど複雑な損傷形態が重畳する. またそれらは材料の種類によっても異なる様相を示す。

図 7 に，オーステナイト系ステンレス鋼 SUS304HTB と焼戻しマルテンサイト組織の Mod.9Cr 鋼について未使 用材ならびにクリープ損傷材の KAM マップを示す.6) SUS304HTB では初期にはほとんど KAM の分布は認め られず，クリープ損傷が増加するにしたがって KAM 值 の高い部分 (図の着色部分) が結晶粒界 $\left(15^{\circ}\right.$ 以上の境 界線）に近い部分から広がっていく。一方，Mod.9Cr 鋼 では，初期に KAM 值の高い部分が粒内（5以上の境界 線）に分布し，損傷が増加するにつれて消失するととも に，境界線で囲まれた粒が粗大化している。このように 


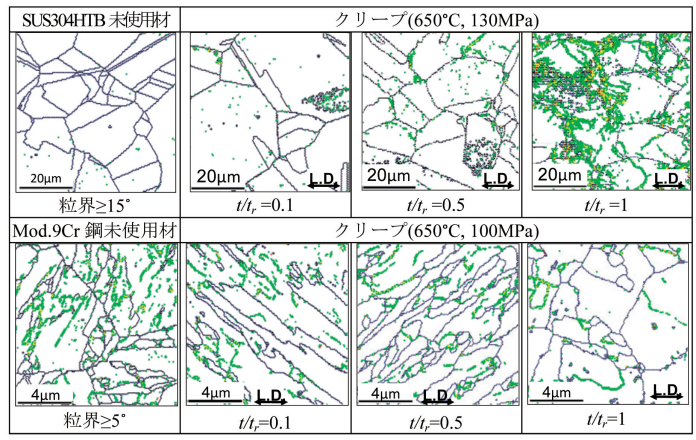

図 7 クリープ損傷過程の KAM マップによる観察

方位差マップは損傷過程を可視化する点では極めて有効 であるが，同じ引張りクリープひずみの蓄積に対して方 位差が反対の傾向を示すことから，クリープひずみにそ のまま対応しているわけではないことがわかる.

米山ら ${ }^{7)}$ は, Mod.9Cr 鋼溶接部クリープ損傷材の細粒 HAZ (Heat Affected Zone) 部における回復・再結晶を伴う 組織の EBSD 観察を行い, 小傾角粒界や大傾角粒界を抽 出し, 粒径の変化に着目した損傷評価法を提案している.

一方，オーステナイト系ステンレス鋼や超合金などに おいては, クリープひずみに対して方位差が単調に増加 することからひずみ評価に関する結果が得られている. 与田ら ${ }^{4)}$ は, 罒 8 に示すように, オーステナイト系ステ ンレス鋼 SUS316について, 初期值からの GAMave の変 化量 $\Delta G A M_{a v e}$ とクリープ損傷率（時間分数）の関係が, クリープ曲線と破断時を除いて同等であることを明らか にしている.

クリープに伴う結晶回転に着目した研究として, 高久 $ら^{8)}$ が， Ni 基合金多結晶材のクリープ損傷を多結晶体の 各結晶粒の配向に着目した検討を行っている．新材の結 晶方位はほぼランダムであるが，クリープが進行するに 従って, 応力軸方向に引き延ばされた比較的大きな結晶 粒と再結晶粒とみられる微細な結晶粒が見られ, 結晶方 位が揃ってくる. 変形しやすい結集粒が優先的に変形し ていることも観察されている。ささらに, 結晶方位の分布と クリープ損傷とを対応づけるために，特定の方位を持つ結 晶粒の増減に着目した定量化の試みとして, パラメータ $P_{<u v w>, \theta}$ を応力軸となす角が $0^{\circ}$ から $\theta^{\circ}$ の間にある領域の 面積率とし, 時間分数 $t / t_{r}$ との関係を調べた結果, 方位 によって単調増加または単調減少の関係を得ている.

また，小林ら ${ }^{9)}$ は，ガスタービン動翼に用いられる $\mathrm{Ni}$ 基超合金 IN738LCについて，き裂発生・成長過程を GROD マップによって追跡し, 表面組織の結晶方位差解

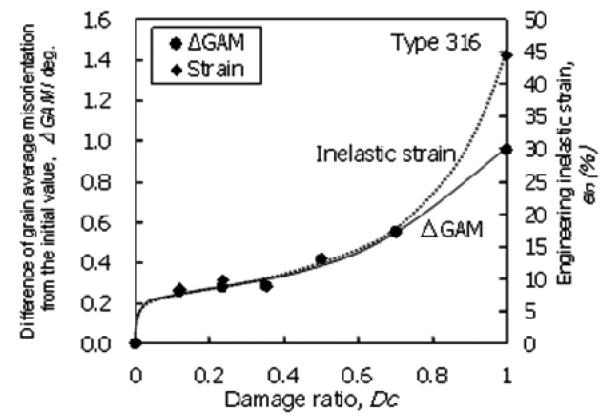

図 8 GAM 変化量とクリープ曲線との対応 ${ }^{4)}$

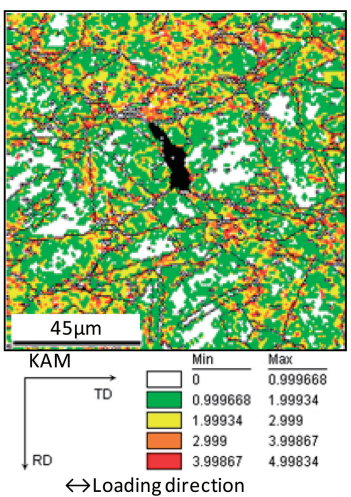

(a)KAM マップ

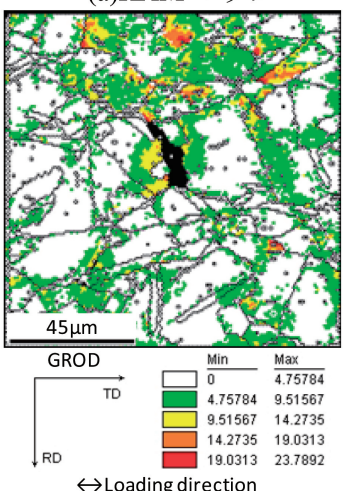

(c)GROD マップ

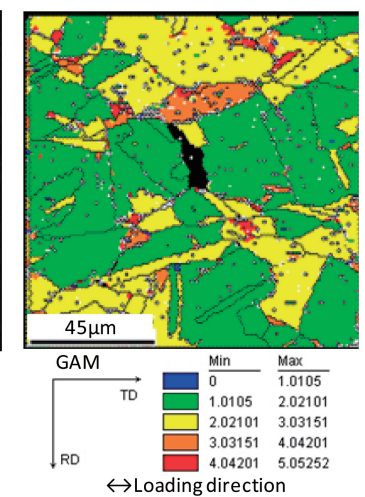

(b)GAM マップ

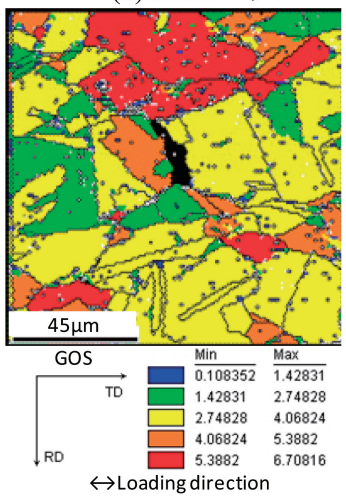

(d)GOS マップ
図 9 IN718のクリープ破断材微小き裂部の EBSD 観察

析を行っている. GROD は, 試料表面や応力集中部の形 状の影響が比較的小さく，また応力集中部近傍の結晶粒 界での方位差の変化が大きいことがわかっている.

クリープ損傷の実体の把握のためには, クリープボイ ドや微小き裂に着目する必要があるが, EBSD 法では方 位差の指定により結晶粒界が判別できるため, これまで ボイド観察に必須となっていた粒界エッチングの必要がほ とんど無いという利点がある。図 9 に, IN718のクリープ 損傷材（損傷率 100\% 相当で破面から離れた部位）につ いて結晶粒界に存在する微小き裂の KAM マップ, GAM マップ, GROD マップ, GOS マップを示す。いずれもき 裂先端部の結晶粒の方位差が高い傾向を示している. KAM マップや GROD マップでは, 結晶粒界近傍に方位 差が集中しており，GAM マップや GOS マップではき裂 先端部の結晶粒の方位差が高いことがわかる.

\section{$3 \cdot 4$ 高温低サイクル疲労およびクリープ疲労損傷評価}

高温低サイクル疲労およびクリープ疲労損傷において は，繰返しのごく初期（破損回数の $10 \%$ 程度以下）に招 いて, バルクの組織変化は飽和傾向を示す。これは, 初 期に微小き裂が発生した後, 次第に主き裂の進展による 局所ひずみ集中が生じるためであると考えられる.

図 10 に, SUS304HTB と Mod.9Cr 鋼についてクリープ 疲労損傷材の KAM マップを示す.6)未使用材組織は困 7 に 示したものと同等である. SUS304HTB ではひずみ繰返 しと共に KAM 值の高い部分が結晶粒界に近い部分から 広がっていく。一方, Mod.9Cr 鋼では, 繰返し数比 $N / N_{f}$ が 0.1 において KAM 值の分布は認められず, 粒も 等方的になり粗大化している.クリープ損傷の場合と同 様であるが，その程度は顕著である. 


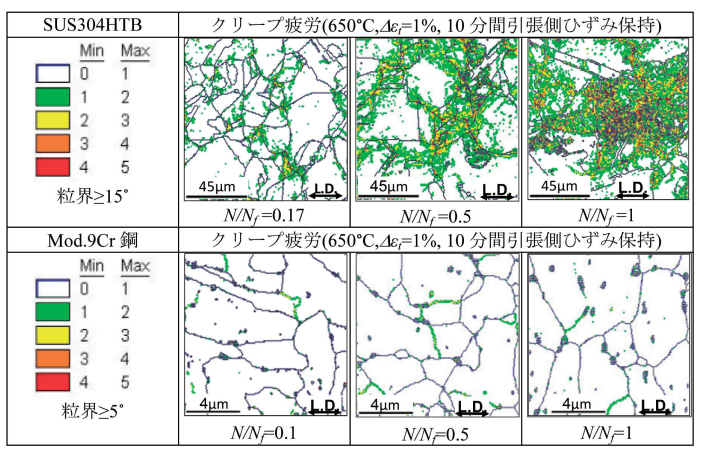

図 10 クリープ疲労損傷過程の KAM マップによる観察

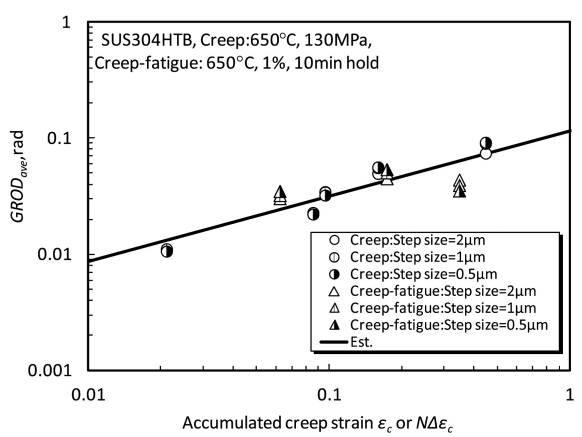

図 11 SUS304HTB のクリープおよびクリープ疲労 に打ける GRODave とクリープひずみまたは累積 クリープひずみ範囲の関係

クリープ疲労試験については，SUS304HTB 鋼におい て図 11 に示すように，GROD ave がクリープ試験におけ るマクロなクリープひずみ $\varepsilon_{c}$ または，クリープ疲労試験 のクリープひずみ範囲 $\Delta \varepsilon_{c}$ (ひずみ保持中の応力緩和量 をヤング率で除した值）に繰返し数 $N$ をかけた累積值 $N \Delta \varepsilon_{c}$ に対してほぼ統一的な単調増加傾向を示す。ただし クリープ疲労試験の破損時のみ飽和傾向が認められる。 Mod.9Cr 鋼においては, 初期に低下しその後ほぼ一定と なる傾向を示し，ひずみの増加に対応する量は見出され ていない.

\section{$3 \cdot 5$ EBSD パラメータと他のパラメータとの関係}

EBSD 観察によって得られる情報は転位分布と密接に 関係するため, 硬さ計測結果とは比較的良く対応する. 硬さ $H V$ は転位密度 $\rho$ の平方根とバーガースベクトル $b$, 剛性率 $\mu$ に比例し, 次式で表されることが多い.

$$
H V=\alpha \mu b \sqrt{\rho}
$$

方位差と転位密度 $\rho$ は比例するものとすると, 硬さ $H V$ と $K A M_{\text {ave }}$ などの方位差パラメータは $1 / 2$ 乗の関係で 表されると考えられ，実際， $10 \mathrm{Cr}$ 鍛鋼について $1 / 2$ 乗の 関係を示唆する結果が得られている. ${ }^{10)}$

また, EBSD は浸入深さが数 $10 \mathrm{~nm}$ 程度の表面観察手 段であることから，表面に現れた可動転位が，容易に抜 け出して緩和することも考慮しなければならない.1) EBSD に比べて材料内部の深いところの平均的情報を得る手段 としてX 線回折法やシンクロトロン放射光を利用した検 証も有効であろう．X線パラメータである過剩転位密度 とクリープひずみは良い対応を示しており，EBSD パラ メータとの対応関係を得ることも可能である.

\section{3 次元 EBSD 観察法}

$4 \cdot 1$ シリアルセクショニング法による結晶粒観察

EBSD では観察面に対し，オイラー角によって 3 次元 の結晶方位情報を得ることができる。しかし，浸入深さ が浅いことから，完全な結晶粒の 3 次元結晶方位情報を 得るためには，表面から層を除去しながら EBSD 観察を 行い，データを再構成して完全な立体情報とする必要が ある. 3 次元観察法として，表面層に変形を与えずに FIB（Focused Ion Beam：集束イオンビーム）装置を用 いて除去していくシリアルセクショニング法が注目され ている.

図 12 に，遮熱コーティングのトップコート層における シリアルセクショニングによる IPF マップの作製例を示 し，図 13 にその結果をもとに作成したスプラット粒と割 れの 3 次元構成例を示す. ${ }^{11)}$ 表面観察では得られなかった, スプラット粒と割れの 3 次元形態が把握でき，コーティ ングはく離損傷解明の有力な手段として注目される.

\section{$4 \cdot 2 \mathrm{SEM}$ との併用によるクリープボイドの 3 次元 観察}

クリープボイドは，特に小さなものは EBSD によって 同定することは困難であるため, SEM 像と EBSD 像と を組合せて判別する方法が山際ら ${ }^{12)}$ にって提案されて いる。最近の装置ではSEM 像と EBSD 像が同じ視野で 傾かない画像として得られるものがあり，両者での同一 画面の観察が容易になってきている。罒 14 に，シリアル セクショニング法によって得られた $\mathrm{CrMoV}$ 鋼のクリー

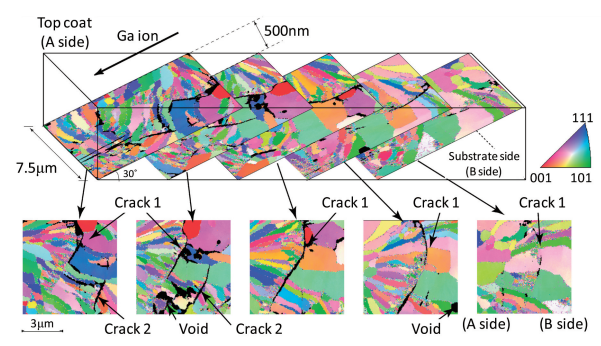

困 12 シリアルセクショニング法による EBSD 観察 ${ }^{11)}$

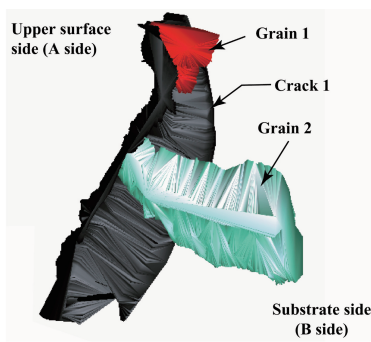

困 13 スプラット粒とき裂の 3 次元再構成 ${ }^{11)}$

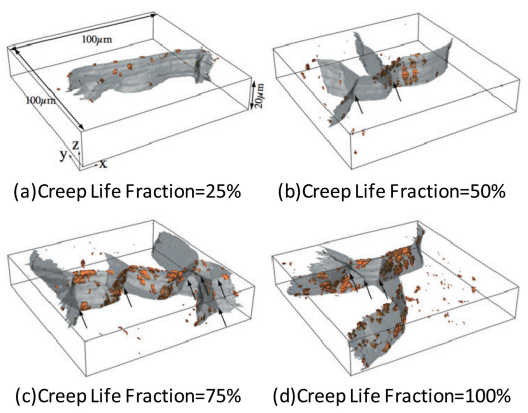

図 14 クリープボイドの 3 次元再構成 ${ }^{12}$ 
プボイドの 3 次元画像構成例を示す. SEM によって得ら れたクリープボイドの 3 次元形状と EBSD によって得ら れた結晶粒界の 3 次元情報が重ねて表示されており，ク リープ損傷の立体分布が表現されている.

\section{EBSD 法と他の観察手法とのハイブリッド解析法} 5・1 EBSD-AFM 観察

高サイクル疲労損傷に対して, AFM (Atomic Force Microscope) 観察では表面のすべり帯や微小き裂による 凹凸像が得られるが，この像と EBSD 観察像から，す心゙ り帯と結晶方位の関係や転位分布情報を明らかにして疲 労き裂発生メカニズムを詳細に調べることができる.5)

\section{$5 \cdot 2$ EBSD-SIM 観察}

SIM (Scanning Ion Microscope) 像は, SEM に比べて も明瞭な組織パターンが得られる。遮熱コーティングに 扎いては，トップコートとボンドコートの界面に生じる 酸化層の観察が重要であるが, トップコートは EBSD に よって, ボンドコートは SIM 像によって観察することに より, 特に界面の酸化層とトップコートのスプラット粒 形態や割れなどの評価が可能となる.11)

\section{$5 \cdot 3$ EBSD 観察と顕微ラマン分光観察}

顕微ラマン分光法では, 結晶構造に関するより詳細か つ厳密なデータが得られることから，トップコート層とボ ンドコート層の間の TGO (Thermally Grown Oxide) 層に 生じる残留応力の計測 ${ }^{13)}$ に応用できる。また, EBSD 法 では困難な部分安定化ジルコニアの正確な結晶同定にも 有効な方法として期待される.

\section{EBSD 観察にもとづく余寿命診断技術の課題と展望}

\section{$6 \cdot 1$ 微小サンプル法への適用}

EBSD 法ではごく微小なサンプルがあれば良いため， 実機からの試料採取も比較的容易である。例えばスモー ルパンチ試験片を採取するときに, 相対する面からサン プルを採取することによって結晶構造を知ることができ る。このことはスモールパンチクリープ試験結果の解析 に極めて有効であると考えられる。 また, スモールパン チ試験後の試料からひずみ分布や結晶変形分布を知るこ とにより, 破損条件をより詳細に知ることができる.

$6 \cdot 2$ 損傷メカニズムにもとづく余寿命診断の高度化 クリープボイドやクリープき裂，クリープ疲労き裂な どの損傷の周囲のひずみ分布を知ることができれば，損 傷発達式の検証やモデルの精度向上に大きく寄与するも のと考えられる.

\section{$6 \cdot 3$ 高温材料開発・改良のための手段}

結晶格子および結晶粒の構造を詳細に把握し，損傷の 起点やその成長則をミク口組織と対応づけて把握するこ とにより，損傷を抑制するための組織等に役立つ情報が 得られるものと期待される.

$$
7 \text { お りに }
$$

EBSD 法は，余寿命診断技術の高度化のための有力な 手法と考えられるが, スキャンに要する時間, 分解能と 精度, 浅い浸入深さ, その場観察の困難さ, など解決す べき課題も多い.しかしこれまでの EBSD 装置の技術進 歩の速さを考えると, 今後さらに装置の革新が進んでい くものと考えられる. 高温に打ける損傷評価は, 表面の みならず内部情報も必要であることから, X 線回折, 超 音波扎よび本稿で述べた FIB 装置やラマン分光装置その 他複数の手段を駆使して損傷の実体に対する理解を深め ていくことが必要である.

\section{参 考 文 献}

1) A. J. Schwartz, M. Kumar, B. L. Adams and D. P. Field, "Electron backscatter diffraction in material science second edition”, Springer, New York (2009).

2) S. Suzuki, "EBSD handbook for OIM users (B2.00)", TSL Solutions Co. (2006).

3) M. Kamaya, A. J. Wilkinson and J. M. Titchmarsh, "Quantification of plastic strain of stainless steel and nickel alloy by electron backscatter diffraction”, Acta Materialia, Vol.54, pp.539-548 (2006).

4) R. Yoda, T. Yokomaku and N. Tsuji, "Plastic deformation and creep damage evaluations of type 316 austenitic stainless steels by EBSD”, Materials Characterization, Vol.61, pp.913-922 (2010).

5 ) Y. Wang, H. Kimura, Y. Akiniwa and K. Tanaka, "EBSDAFM hybrid analysis on early fatigue damage in austenitic stainless steel under cyclic torsional loading”, Journal of the Society of Materials Science, Japan, Vol.55, No.10, pp.936-943 (2006).

$6)$ K. Fujiyama, H. Kimachi, Y. Watanabe, K. Hijikuro and T. Tsuboi, "The concept of "EBSD strain analysis" and its application to creep and creep-fatigue damage assessment of ferritic and austenitic heat resistant steels”, Strength, Fracture and Complexity, Vol.7, pp.123-135 (2011).

$7)$ N. Yoneyama, K. Kubushiro and H. Yoshizawa, "Creep damage evaluation of fine-grained $\mathrm{HAZ}$ in Mod.9Cr ferritic heat-resistant steel weldments", Proceedings of Creep 8, ASME, CREEP2007-26726, pp.1-5 (2007).

8) R. Takaku, D. Saito and Y. Yoshioka, "Change of grain orientation and effect of grain size on It in creep deformed Hastelloy-X”, Testu-to-Hagane, Vol.95, No.2, pp.154-160 (2009).

$9)$ D. Kobayashi, M. Miyabe, Y. Kagiya, Y. Nagumo, R. Sugiura, T. Miyazaki and A. T. Yokobori Jr, “Creep damage evaluation of IN738LC based on the EBSD method by using a notched specimen”, Strength, Fracture and complexity, Vol.7, pp.157-167 (2011).

10) K. Fujiyama, K. Mori, D. Kaneko, H. Kimachi, T. saito, R. Ishii and T. Hino, "Creep damage assessment of $10 \mathrm{Cr}-1 \mathrm{Mo}-$ $1 \mathrm{~W}-\mathrm{VNbN}$ steel forging through EBSD observation", International Journal of Pressure Vessels and Piping, Vol.86, pp.570-577 (2009).

11) H. Kimachi, W. Ota, M. Uchimura, K. Fujiyama, H. Nakaseko and N. Egami, "Microstructure evaluation of thermal barrier coatings by serial sectioning technique combined with FIB-Milling/EBSD”, Netsu Syori, Vol.49, No.5, pp.233-234 (2009).

12) K. Yamagiwa, S. Kataoka, S. Izumi and S. Sakai, "Measurement of three dimensional geometry of creep void and grain boundary with combining 3D-EBSD method and SEM images”, Transactions of the Japan Society of Mechanical Engineers, A, Vol.76, No.772, pp.1799-1805 (2010).

13) H. Kimachi, W. Ota, K. Fujiyama, S. Yamamoto, K. Miwa and D. Kaneko, "Evaluation of thermal damage of thermal barrier coatings by using raman microspectroscopy", Journal of the Society of Materials Science, Japan, Vol.59, No.6, pp.455-461 (2010). 